\title{
Hydrochemical Characteristics of High-fluorine Groundwater in the Plain of the Yarkant River Basin, Northwest China
}

\author{
Jie Zhang ${ }^{1,2}$, Jinlong Zhou ${ }^{1,2, *}$, Yinzhu Zhou ${ }^{3, * *}$, Yanyan Zeng ${ }^{1,2}$, and Yunfei Chen ${ }^{1,2}$ \\ ${ }^{1}$ College of Water Conservancy and Civil Engineering, Xinjiang Agricultural University, Urumqi, \\ 830052, P.R.China \\ ${ }^{2}$ Xinjiang Hydrology and Water Resources Engineering Research Center, Urumqi, 830052, P.R.China \\ ${ }^{3}$ Key Laboratory of Drinking Water Science and Technology, Research Center for Eco- \\ Environmental Sciences, Chinese Academy of Sciences, Beijing 100049, P.R.China
}

\begin{abstract}
Study on regional distribution of high-fluorine groundwater will help to understand migration and transformation of fluorine, and provide the theoretical basis of low-fluorine groundwater exploration in high-fluorine groundwater areas. In this study, 74 shallow groundwater samples collected from plain area of the Yarkant River Basin in Xinjiang were analyzed. Results showed that the type I (low-fluorine groundwater, $\mathrm{F}^{-}<1 \mathrm{mg} / \mathrm{L}$ ) was distributed in the piedmont plain, the type II (high-fluorine groundwater, $1 \mathrm{mg} / \mathrm{L} \leq \mathrm{F}^{-}<2 \mathrm{mg} / \mathrm{L}$ ) was distributed in the central and northeastern part of the basin, and the type III (high-fluorine groundwater $\mathrm{F}^{-} \geq 2 \mathrm{mg} / \mathrm{L}$ ) was continuously distributed along the flow direction of river water in the western part of the basin. The average concentration of groundwater fluorine was $1.26 \mathrm{mg} / \mathrm{L}$, with an exceeding standard rate of $48.65 \%$. Groundwater cations were dominated by $\mathrm{Ca}^{2+}$ and $\mathrm{Mg}^{2+}$ and anions were dominated by $\mathrm{SO}_{4}{ }^{2-}$ and $\mathrm{Cl}^{-}$. High-fluorine groundwater occurred under neutral to weak alkaline environment with $\mathrm{pH}$ ranged between 6.61 and 7.99 , which is favorable for the dissolution of fluorinebearing minerals. Average concentration of total dissolved solids (TDS) in type I, type II and type III groundwater were $1657 \mathrm{mg} / \mathrm{L}, 3522 \mathrm{mg} / \mathrm{L}$ and $3724 \mathrm{mg} / \mathrm{L}$, respectively. High-fluoride groundwater generally had high TDS concentrations.
\end{abstract}

\section{Introduction}

Fluorine (F) is an essential trace element for the human body, which can promote the development of bone and teeth. However, excessive intake of fluoride will lead to fluorosis [1]. According to the National Standard of Drinking Water Quality (GB5749-2006), F concentration in drinking water is between 0.5 and $1.0 \mathrm{mg} / \mathrm{L}$. Groundwater with $\mathrm{F}$ concentration greater than $1.0 \mathrm{mg} / \mathrm{L}$ is defined as high-F groundwater [2]. High-F groundwater have been found in Xinjiang such as Akesu, Kuitun, Hetian, Shihezi and

\footnotetext{
*Corresponding author: zjzhoujl@163.com（JL Zhou）

**Correspondence to: yinzhu_zhou@qq.com (YZ Zhou)
} 
Yarkant River Basin [3-7]. However, there are few studies on the hydrochemistry of groundwater with high F concentrations in the Yarkant River Basin in the eastern part of Kashi, Xinjiang.

The Yarkant River Basin can be divided into two zones, piedmont zone and alluvial plain area, according to hydrogeological settings and topography. The aquifer in southern part of the alluvial plain zone is composed of coarse sand and fine sand, which is thicker and water-rich. The northern part of the plain area is composed of fine silt, silt and silty clay, which the hydraulic gradient is small and the groundwater runoff is hindered. Irrigation area of the Yarkant River Basin is the largest irrigation area in Xinjiang, covering an area of $8.58 \times 10^{4} \mathrm{~km}^{2}$. The regional ecological environment has been deteriorated with increasing population and irrigation areas, which affect the sustainable utilization of regional water resources [8]. Therefore, research on distribution and influence factors of groundwater $\mathrm{F}$ in shallow aquifers in this area provided theoretical basis for regional groundwater security. The purposes of this study were (1) to investigate the characterize geochemistry in the Yarkant River Basin and (2) to identify the major hydrogeochemical processes controlling groundwater $\mathrm{F}$ concentrations.

\section{Materials and Methods}

\subsection{Groundwater sampling}

In the study, 74 shallow groundwater (buried depth $<100 \mathrm{~m}$ ) samples were collected from June to July 2014 (Fig. 1). Groundwater samples were preserved and analyzed according to the Technical Specification of Groundwater Environment Monitoring (HJ/T164-2004).

\subsection{Groundwater samples testing}

Groundwater $\mathrm{pH}$, temperature, dissolved oxygen (DO), redox potential (Eh), conductivity (EC) were determined in the field. Groundwater major components (including $\mathrm{K}^{+}, \mathrm{Na}^{+}$, $\mathrm{Ca}^{2+}, \mathrm{Mg}^{2+}, \mathrm{Cl}^{-}, \mathrm{SO}_{4}{ }^{2-}, \mathrm{HCO}_{3}{ }^{-}, \mathrm{CO}_{3}{ }^{2-}$ ), minor components (including $\mathrm{F}^{-}$) and total dissolved solids (TDS) were determined in the Mineral Water Testing Center of the Institute of Hydrogeology and Environmental Geology at the Chinese Academy of Geological Sciences.

\section{Results and discussion}

\subsection{Spatial distribution of groundwater fluoride}

According to $\mathrm{F}$ concentrations, groundwater in the plain area in the Yarkant River Basin was classified into three types: type I $\left(\mathrm{F}^{-}<1 \mathrm{mg} / \mathrm{L}\right)$, type II $\left(1 \mathrm{mg} / \mathrm{L} \leq \mathrm{F}^{-}<2 \mathrm{mg} / \mathrm{L}\right)$, and type III $\left(\mathrm{F}^{-} \geq 2 \mathrm{mg} / \mathrm{L}\right)$. Type I groundwater had low $\mathrm{F}$ concentration, while type II and type III groundwater had high $\mathrm{F}$ concentration [9]. $\mathrm{F}$ concentrations in groundwater ranged between 0.36 and $5.20 \mathrm{mg} / \mathrm{L}$ with an average of $1.26 \mathrm{mg} / \mathrm{L}$. There are 36 groundwater samples in which $\mathrm{F}$ concentration were greater than $1 \mathrm{mg} / \mathrm{L}$, with the exceeding standard rate of $48.65 \%$. GIS software and the Kriging interpolation method were used to plot the spatial distribution diagram of groundwater F (Fig. 1). Type I groundwater was mainly distributed in the piedmont plain located in the southwestern study area. Type II groundwater was widely distributed in the middle and northwest of the study area. Type III groundwater was continuously distributed along both sides of the river in the west. In general, low-F groundwater was mainly distributed in the piedmont plain of the Yarkant River which 
mainly recharged laterally by rivers. High-F groundwater was widely distributed in the agricultural irrigation area where the groundwater was mainly recharged by irrigation water leakage, and discharged via evaporation, artificial exploitation and lateral runoff. Groundwater $\mathrm{F}$ enrichment in the agricultural irrigation area mainly resulted from phreatic water evaporation.

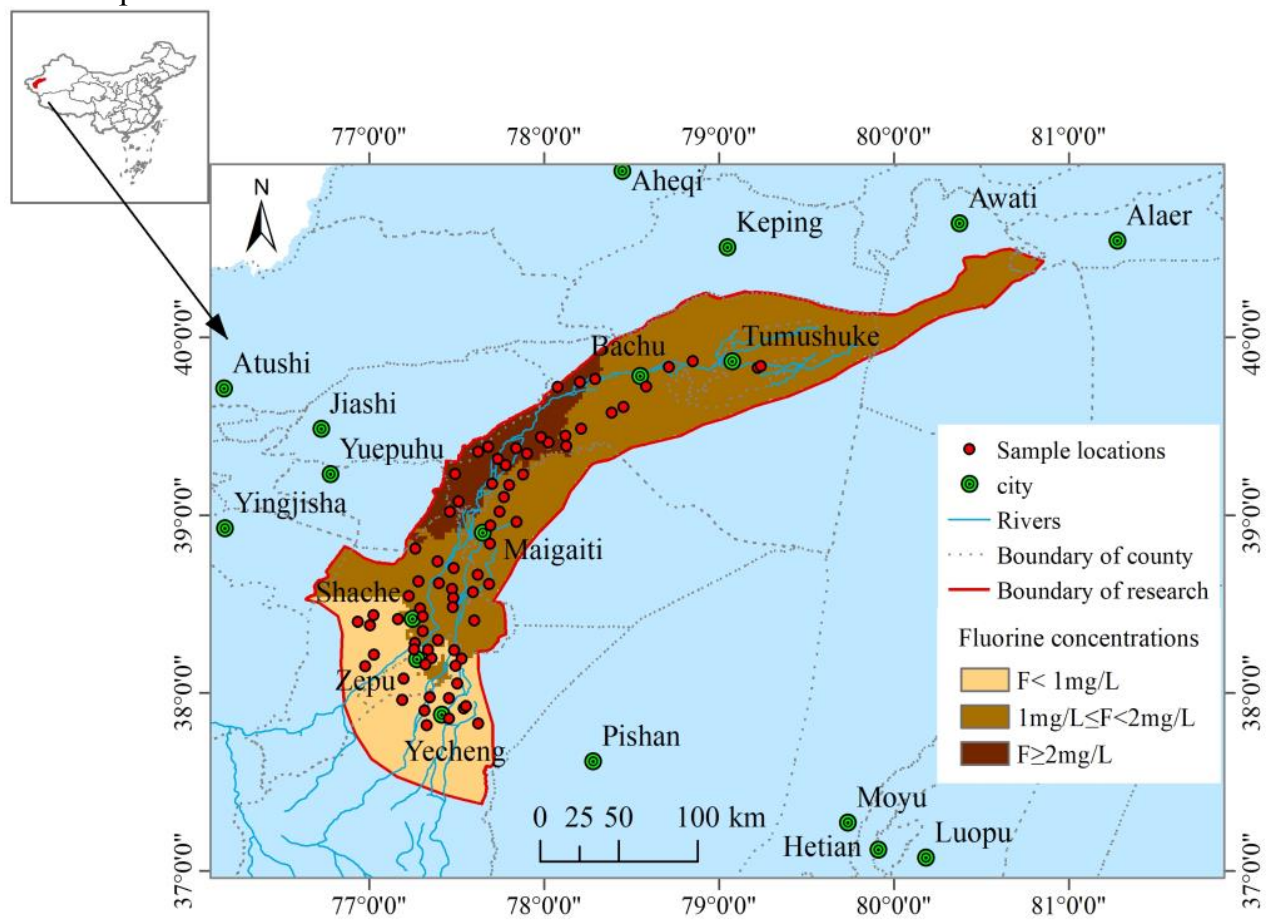

Fig. 1. Distribution of groundwater F concentrations in plain area in the Yarkant River Basin.

\subsection{Groundwater chemical characteristics}

The groundwater facies is of $\mathrm{SO}_{4} \cdot \mathrm{Cl}-\mathrm{Na} \bullet \mathrm{Ca}, \mathrm{SO}_{4} \cdot \mathrm{Cl}-\mathrm{Na} \bullet \mathrm{Mg}$ and $\mathrm{HCO}_{3} \bullet \mathrm{SO}_{4}-\mathrm{Ca} \bullet \mathrm{Mg}$ type (Fig. 2). The meq percentage of $\mathrm{Mg}^{2+}$ in cations was less than $40 \%$ with little changes while the meq percentage of $\mathrm{Ca}^{2+}$ and $\mathrm{Na}^{+}+\mathrm{K}^{+}$in cations varied between low-F and high-F groundwaters. Compared with low-F groundwater, high-F groundwater (with $\mathrm{F}^{-}>2 \mathrm{mg} / \mathrm{L}$ ) usually had larger meq percentage of $\mathrm{Ca}^{2+}$ (29.64\%-53.97\%). As for anions, high-F groundwater (with $\mathrm{F}^{-}>2 \mathrm{mg} / \mathrm{L}$ ) had larger meq percentage of $\mathrm{SO}_{4}{ }^{2-}(28.91$ to $72.48 \%$ ). 


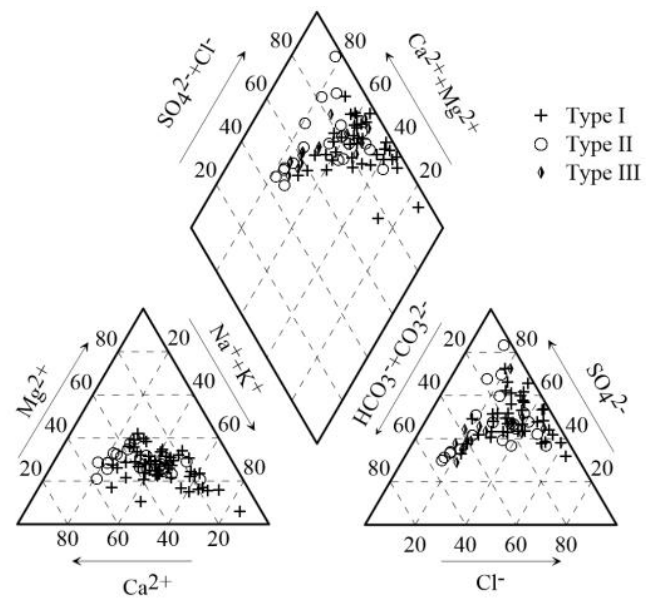

Fig. 2. Piper diagram of shallow groundwater in the study area.

\subsection{Relationship between groundwater $\mathrm{F}$ and $\mathrm{pH}$}

High-F groundwater mainly occurred under neutral to alkaline environment with $\mathrm{pH}$ ranged from 6.61 to 8.07 (Fig. 3). Type I groundwater $\left(\mathrm{F}^{-}<1 \mathrm{mg} / \mathrm{L}\right)$ had $\mathrm{pH}$ ranged between 7.05 and 8.07 with an average of 7.64. Type II groundwater $\left(1 \leq \mathrm{F}^{-<2} \mathrm{mg} / \mathrm{L}\right)$ had $\mathrm{pH}$ ranged between 6.94 and 7.84 with an average of 7.45. Type III groundwater $\left(\mathrm{F}^{-} \geq 2 \mathrm{mg} / \mathrm{L}\right)$ had $\mathrm{pH}$ ranged between 6.61 and 7.99 with an average of 7.32. Acidity and alkalinity of groundwater were not the direct reasons for fluorine concentrations. However, F-bearing minerals dissolution was liable to occur under weak alkaline environment, leading to $\mathrm{F}$ enrichment in groundwater [10].

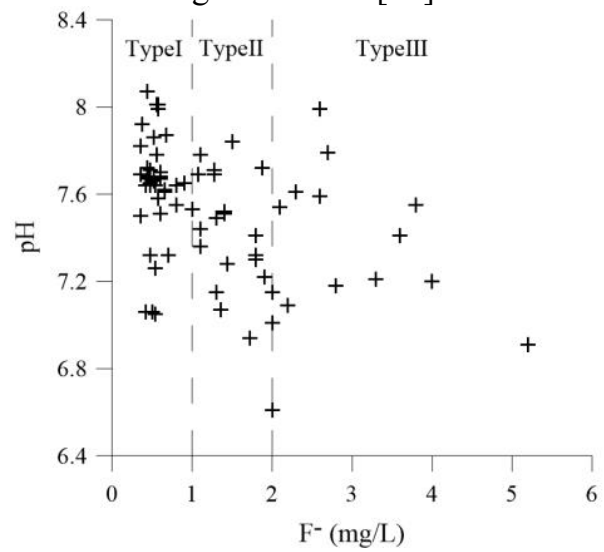

Fig. 3. Relationship between $\mathrm{F}^{-}$concentration and $\mathrm{pH}$ in groundwater.

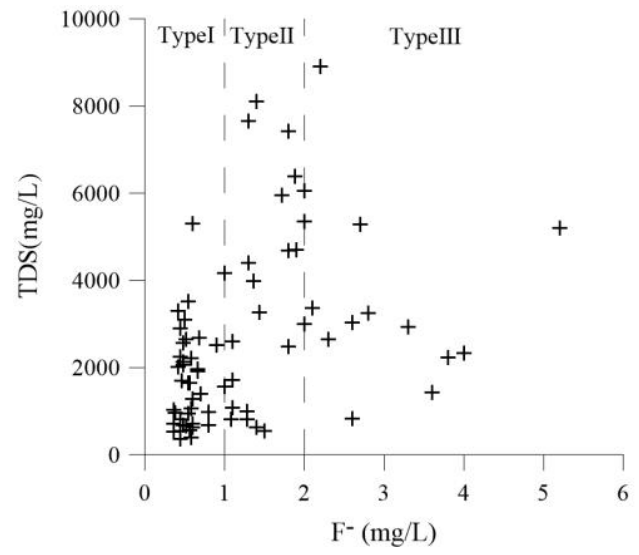

Fig. 4. Relationship between $\mathrm{F}^{-}$concentration and TDS in groundwater.

\subsection{Relationship between groundwater F and TDS}

TDS concentrations in type I groundwater ranged between $367 \mathrm{mg} / \mathrm{L}$ and $5301 \mathrm{mg} / \mathrm{L}$ with an average of $1657 \mathrm{mg} / \mathrm{L}$. TDS concentrations in type II groundwater ranged between 546 and $8104 \mathrm{mg} / \mathrm{L}$ with an average of $3522 \mathrm{mg} / \mathrm{L}$ and that in type III groundwater ranged between 828 and $8910 \mathrm{mg} / \mathrm{L}$ with an average of $3724 \mathrm{mg} / \mathrm{L}$. Compared with low-fluorine 
groundwater, high-fluorine groundwater had larger average TDS (Fig. 4). Hindered runoff and evaporation and concentration of groundwater often lead to the increase of TDS, which result in $\mathrm{F}^{-}$enrichment. In other words, higher-F groundwater generally had high TDS concentrations [11].

\section{Conclusions}

Groundwater $\mathrm{F}$ in shallow aquifers in the plain area in the Yarkant River Basin in Xinjiang were determined. The distribution of High-F groundwater and influence factors were analyzed. Major conclusions were drawn as follows:

(1) Groundwater fluoride concentrations ranged between 0.36 and $5.20 \mathrm{mg} / \mathrm{L}$ (average of $1.26 \mathrm{mg} / \mathrm{L}$ ) in the plain area of the Yarkant River Basin. The exceeding standard rate was $48.65 \%$. High-F groundwater was mainly distributed in the central and northeastern areas. In the area, natural factors (slow runoff and intensive evaporation) and human activities such as agricultural irrigation play an important role to $\mathrm{F}$ enrichment in groundwater.

(2) In the study area, $\mathrm{Ca}^{2+}$ and $\mathrm{Na}^{+}$were the main cations in groundwater, while $\mathrm{SO}_{4}{ }^{2-}$ and $\mathrm{Cl}^{-}$were the main anions. High-F groundwater had greater meq percentage of $\mathrm{Mg}^{2+}$ and smaller meq percentage of $\mathrm{Na}^{+}$.

(3) High-F groundwater usually occurred under neutral to weak alkaline environment, which provide favorable conditions for F-bearing minerals dissolution and groundwater $\mathrm{F}$ enrichment. With the increase of groundwater TDS, F concentrations generally increased. High-F groundwater commonly occurred in saline groundwater.

The survey was funded by the National Natural Science Foundation of China (NSFC) project "Research on Groundwater Salinization Mechanism in Kashgar Area of Xinjiang" (4166 2016); China Geological Survey Project (1212011220982) and the Xinjiang Uygur Autonomous Region Peak Discipline-Water Engineering Discipline Fund (xjslgcgfxk20161116).

\section{References}

1. T. Rafique, S. Naseem, MI. Bhanger, TH. Usmani. Envir. Geol. 56, 2 (2008)

2. C. H. Liu, W. Wang, Z. R. Wei, S. Shang, Z. Zhuo. Acta Geosc. Sinica, 39, 3 (2018) (in Chinese)

3. Q. Li, R. L Jia, J. L. Zhou, Y. P. Wang. Journ. of Arid Land Res. and Envir., 27, 12 (2013) (in Chinese)

4. J. Li, Y. L Luo, Y. H. Yu. Envir. Protect. Scien., 42, 2 (2016) (in Chinese)

5. L. Li, J. L. Zhou, W. Q. Qi, F. Chen, Y. Y. Zeng, Y. F. Chen. Journ. of Arid Land Res. and Envir.,t 33, 1 (2019) (in Chinese)

6. F. J. Luan, Y. ZH. Zhou, J. L. Zhou, R. L. Jia, Y. Y. Zeng. Yellow River, 38, 3 (2016) (in Chinese)

7. F. J. Luan, J. L. Zhou, Y. Y. Zeng, Y. X. Gao, J. T. Liu. Envir. Chem., 35, 6 (2016) (in Chinese)

8. J. Shi, L. Q. Xue, X. F. Chen, L. C. Zhang, C. Sun. Jour. of Wat. Res. and Water Eng., 28, 5 (2017) (in Chinese)

9. X. Q. Li, L. R. Zhu, X. W. Hou, L. Zhang. Acta Geos. Sin., 28, 1 (2007) (in Chinese)

10. C. Su, Y. Wang, X. Xie, J. Li. Jour. of Geoch. Exp., 135, 6 (2013)

11. A. G. S. Ressy, D. V. Reddy, M. S. Kumar. Envir. Earth Scien., 75, 8 (2016) 